\title{
Pengembangan Perangkat Pembelajaran Berbasis Subject Specific Pedagogy (SSP) Terintegrasi Pendidikan Karakter dan Revolusi Mental untuk SD/MI di Bandarlampung
}

\author{
Nurul Hidayah \\ IAIN Raden Intan Bandarlampung \\ ida.hidayah05@gmail.com
}

\begin{abstract}
This study aims to: 1) developing a learning device integrates character education and mental revolution based of Subject Specific Pedagogy (SSP) for Vocabulary School in Bandar Lampung; 2) describe the learning device feasibility integrated character education and mental revolution based of Subject Specific Pedagogy (SSP) for Vocabulary School in Bandar Lampung; and 3) determine the achievement of learning. This research is conducted with the design of Research and Development, ie research which seeks to design and create prototype learning device with certain specifications. Subjects SDN 1 Constable, SDN 1 Kaliawi, and SDN 2 Sumur Batu. The procedures of research data analysis are: 1) tabulate data from questionnaires and interviews; 2) analyze data on the tabulation; 3) interpret results tabulation; 4) concluded; and 5) analyzing the data obtained from the survey results. Research results : 1) Development is done using a seven-step Research and Development has produced a learning device Indonesian sixth grade elementary school-based Subject Specific Pedagogy (SSP) integrates character education; 2) The quality of products developed learning device gain value with excellent category; 3) The achievement of learning outcomes in most aspects of high character is honest, curiosity, discipline, and hard work.
\end{abstract}

Keywords: Learning Device, Subject Specific Pedagogy (SSP), Character Education, Mental Revolution

Abstrak: Pembelajaran ini bertujuan untuk: 1) mengembangkan
sebuah pembelajaran perangkat integrasi sikap pendidikan dan revolusi
mental berdasarkan dari subjek pedagogik yang spesifik (SSP) dan 3)
menentukan pencapaian dari hasil pembelajaran Penelitian ini
dilaksanakan dengan desain penelitian dan pengembangan, penelitian
yang akan melihat kepada desainnya dan menciptakan prototipe
perangkat pembelajaran dengan spesifikasi yang sudah jelas. Subjeknya
adalah 3 SD di Bandar Lampung yaitu SDN 1 Polisi, SDN 1 kaliawi
dan SDN 2 Sumur Batu. Prosedur dari penelitian data analisis adalah:

AR-RIAYAH : Jurnal Pendidikan Dasar vol. 2, no. 1, 2018

STAIN Curup - Bengkulu| p ISSN 2580-362X; e ISSN 2580-3611

http://journal.staincurup.ac.id/index.php/JPD 
1) table data pertanyaan dan wawancara; 2) data analisis dari tabel; 3) mengartikan hasil dari tabel; 4) perangkuman dan analisis data. Hasil penelitian ini yaitu: 1) pengembangan sudah dilakukan menggunakan tujuh langkah penelitian pengembangan sudah menghasilkan sebuah perangkat pembelajaran Indonesia berdasarkan subject pedagogic yang spesifik (SSP) terintegrasi pada sikap pendidikan; 2) kualitas dari produk mengembangkan perangkat pembelajaran meningkatkan nilai dengan kategori yang sangat bagus; 3) pencapaian dari hasil pembelajaran dari berbagai aspek dari sikap tertinggi yaitu kejujuran, rasa ingin tahu, disiplin, dan bekerja keras.

Kata Kunci: Perangkat Pembelajaran, Subjek Pedagogik yang Spesifik (SSP)

\section{PENDAHULUAN}

Pembangunan bangsa di segala sendi kehidupan harus dengan mendahulukan pembangunan karakter (character building). Character building inilah yang akan membuat Indonesia menjadi bangsa yang besar, maju, dan jaya serta bermartabat ${ }^{1}$. Pengembangan pendidikan karakter adalah sebuah proses berkelanjutan dan tidak pernah berakhir (never ending process). Selama sebuah bangsa ada dan ingin tetap eksis, pendidikan karakter harus menjadi bagian terpadu dari pendidikan alih generasi.

Guru sebagai ujung tombak pendidikan, memiliki peran yang sangat sentral dalam mewujudkan siswa yang berkarakter. Guru selain dituntut untuk menyampaikan materi, juga dituntut untuk menjadi guru "digugu dan ditiru" yang sebenarnya. Guru harus bisa menanamkan moral, nilai etika, estetika, dan budi pekerti yang luhur. Guru dapat memberi penghargaan (prizing) kepada yang berprestasi dan hukuman kepada yang melanggar, menumbuh suburkan (cherising) nilai-nilai yang baik dan sebaliknya mengecam dan mencegah (discowaging) berlakunya nilai-nilai yang buruk. ${ }^{2}$

Paparan di atas merupakan prasyarat yang harus dimiliki guru profesional. Guru profesional adalah yang menguasai sisi keprofesionalannya, baik soft skills maupun hard skills, berperan serta dalam meningkatkan mutu

${ }^{1}$ Wahyu. 2011, Masalah \& Usaha Membangun Karakter Bangsa, Artikel. Jurnal Komunitas, 138-149

${ }^{2}$ Zuhdan Prasetyo K., dkk. 2011. "Pengembangan Subject Specific Pedagogy (SSP) Berbasis Lima Domain Sains Untuk Menanamkan Karakter Siswa SMP". Makalah Seminar "Peranan Budaya dan Inovasi Pembelajaran dalam Pemantapan Pendidikan Karakter" Unika Atmajaya Jakarta, 15-27 
pendidikan nasional, memiliki landasan kapasitas berupa karakter yang kuat, dan menghargai keragaman sebagai perekat integrasi bangsa. Seorang guru dalam menjalankan tugasnya sebagai pendidik di sekolah perlu memiliki seperangkat ilmu tentang bagaimana ia harus mendidik anak. Guru bukan hanya sekedar terampil dalam menyampaikan bahan ajar, tetapi di samping itu ia juga harus mampu mengembangkan pribadi anak, mengembangkan watak anak, dan mengembangkan serta mempertajam hati nurani anak.

Guru diharapkan lebih mampu bekerja sebagai tenaga profesional dalam melaksanakan tugas dan tanggung jawabnya. Guru dituntut memiliki prestasi dan kecakapan dalam profesi kerjanya. Prestasi kerja tersebut, sesuai tupoksinya, berada dalam bidang kegiatannya: (1) pendidikan, (2) proses pembelajaran, (3) pengembangan profesi dan (4) penunjang pembelajaran. Oleh karena itu, perlu sistem pembentukan profesionalisme sejak dari calon guru hingga pembinaan profesionalisme setelah menjadi guru secara berkesinambungan. Terlebih lagi, bagi guru-guru yang tinggal di daerah. Perlu pembinaan yang serius dan continue, dan berkesinambungan bagi guru-guru terkait dengan pengembangan perangkat pembelajaran (silabus, RPP, materi, bahan ajar, rancangan evaluasi, dan lainlain).

Berdasarkan paparan masalah yang dihadapi dalam pengembangan materi ajar yang tepat bagi siswa, baik di sekolah maupun di rumah, maka penulis melakukan pengembangan melalui penelitian berkaitan dengan pengembangan perangkat pembelajaran berbasis Subject Specific Pedagogy (SSP) terintegrasi pendidikan karakter dan revolusi mental untuk SD/MI di Bandar Lampung .

Adapaun tujuan penelitian ini yaitu : 1. mengembangkan perangkat pembelajaran terintegrasi pendidikan karakter dan revolusi mental berbasis Subject Specific Pedagogy (SSP) untuk SD di Bandar Lampung. 2. mendeskripsikan kelayakan perangkat pembelajaran terintegrasi pendidikan karakter dan revolusi mental berbasis Subject Specific Pedagogy (SSP) untuk SD di Bandar Lampung. 3. mengetahui pencapaian hasil belajar pada aspek karakter yang paling tinggi adalah jujur, rasa ingin tahu, disiplin, dan kerja keras. Kemudian manfaat hasil penelitian ini diharapkan dapat : 1. memberikan sumbangan dan informasi bagi masyarakat dan dunia pendidikan, yaitu dalam pengembangan Subject Specific Pedagogy, khususnya bagi guru-guru di SD. 2. dapat dijadikan bahan masukan bagi guru untuk mengembangkan perangkat pembelajaran. 3. memberikan masukan bagi guru untuk senantiasa berusaha menumbuhkan, memelihara, dan 
meningkatkan pemahamannya dalam mengembangkan perangkat pembelajaran yang efektif bagi siswa.

\section{LANDASAN TEORI}

\section{Perangkat Pembelajaran Subject Specific Pedagogy (SSP)}

Subject Specific Pedagogy (SSP) adalah pengemasan seluruh komponen/perangkat pembelajaran yang diperlukan guru ketika mengajar yang komprehensif. Landasan dalam mengembangkan SSP sesuai dengan PP No. 19 Tahun 2005 Pasal 17 ayat 2 yang berbunyai "sekolah dan komite sekolah atau madrasah dan komite madrasah, mengembangkan kurikulum satuan pendidikan dan silabusnya berdasarkan kerangka dasar kurikulum dan standar kompetensi lulusan di bawah supervisi dinas kabupaten/kota yang bertanggung jawab di bidang pendidikan untuk SD, SMP, SMA, dan SMK dan departemen yang mengenai urusan pemerintahan di bidang agama untuk MI, MTs, MA, dan MAK. Perencanaan pembelajaran meliputi silabus dan rencana pelaksanaan pembelajaran yang memuat sekurang-kurangnya tujuan pembelajaran, materi ajar, metode pengajaran, sumber belajar, dan penilaian hasil belajar. Komponen perangkat RPP sesuai Subject Specific Pedagogy sebagai berikut :

Tabel 1 : Komponen Perangkat RPP Sesuai Subject Specific Pedagogy

\begin{tabular}{|c|c|c|c|}
\hline 1) & Identitas RPP & 16) Tabel spesifikasi LP & 31) Model/strategi/m \\
\hline 2) & $\begin{array}{l}\text { Standar } \\
\text { Kompetensi (SK) }\end{array}$ & $\begin{array}{l}\text { 17) LP terkait dengan } \\
\text { kognitif }\end{array}$ & $\begin{array}{l}\text { etode sesuai } \\
\text { indicator }\end{array}$ \\
\hline 3) & $\begin{array}{l}\text { Kompetensi } \\
\text { Dasar (KD) }\end{array}$ & $\begin{array}{l}\text { 18) LP terkait dengan } \\
\text { kinerja }\end{array}$ & $\begin{array}{l}\text { 32) Fase-fase model } \\
\text { ditulis di RPP }\end{array}$ \\
\hline 4) & Indikator kognitif & $\begin{array}{l}\text { 19) LP terkait dengan } \\
\text { afektif }\end{array}$ & $\begin{array}{l}\text { 33) RPP mendorong } \\
\text { minds on activity }\end{array}$ \\
\hline 6) & $\begin{array}{l}\text { Indikator } \\
\text { psikomotor }\end{array}$ & $\begin{array}{l}\text { 20) LP terkait dengan } \\
\text { psikomotor }\end{array}$ & $\begin{array}{l}\text { 34) RPP mendorong } \\
\text { minds on activity }\end{array}$ \\
\hline 7) & Indikator afektif & 21) Kunci LP & $\begin{array}{l}\text { 35) RPP mendorong } \\
\text { penerapan ICT }\end{array}$ \\
\hline 8) & Tujuan & 22) Media & 36) RPP mendorong \\
\hline 9) & $\begin{array}{l}\text { Pembelajaran (TP) } \\
\text { TP menggunakan } \\
\text { format ABCD }\end{array}$ & $\begin{array}{l}\text { 23) BS menunjang } \\
\text { indicator } \\
\text { 24) LKS menunjang }\end{array}$ & $\begin{array}{l}\text { berkembangnya } \\
\text { strategi belajar } \\
\text { siswa }\end{array}$ \\
\hline
\end{tabular}




\begin{tabular}{ll}
\hline 10) Buku Siswa (BS) & indicator \\
11) LKS Terkait & 25) LP menunjang \\
dengan kognitif & indicator \\
12) LKS terkait & 26) Media menunjang \\
dengan kinerja & indicator \\
13) LKS terkait & 27) BS diskenariokan di \\
dengan & RPP \\
psikomotor & 28) LKS diskenariokan di \\
14) LKS dengan & RPP \\
afektif & 29) LP diskenariokan di \\
15) Kunci LKS & RPP \\
& 30) Media diskenariokan \\
& dnegan RPP
\end{tabular}

\section{Pendidikan Karakter (Pilar Kebangsaan)}

Istilah character education memiliki dua pengertian. Dalam arti luas Kohn berpendapat bahwa:

"Character education refers to almost anything that schools might try to provide outside of academics, especially when the purpose is to help children grow into good people". Sedangkan dalam arti sempit "it denotes a particular style of moral training, one that reflects particular values as well as particular assumptions about the nature of children and how they learn." 3

Karakter didefinisikan secara berbeda-beda oleh berbagai pihak. Albertus memberi pengertian pendidikan karakter di Indonesia sebagai sebuah usaha sadar untuk mengembangkan keseluruhan dinamika relasional antar pribadi dengan berbagai macam dimensi ${ }^{4}$

Pendidikan karakter memliki makna yang lebih dari pendidikan moral, karena pendidikan karakter tidak hanya bekaitan dengan masalah benar-salah, tetapi terkait juga dengan bagaimana menanamkan kebiasaan dalam kehidupan,

3 Noll, James WM, Taking Sides: Clashing Views On Controversial Educational Issues, (United States of America: McGraw-Hill/Duskin, 2006), 102.

4 Albertus, Doni Koesoema, Pendidikan Karakter Strategi Mendidik Anak di Zaman Global, (Jakarta: Garsindo, 2010), 79. 
sehingga peserta didik memiliki kesadaran dan pemahaman yang tinggi serta kepeduliaan dan komitmen untuk menerapkan kebajikan dalam kehidupan sehari-hari.5 Menurut Suyanto, karakter adalah cara berpikir dan berperilaku yang menjadi ciri khas tiap individu untuk hidup bekerja sama, baik dalam lingkungan keluarga, masyarakat, bangsa dan negara. Individu yang berkarakter baik adalah individu yang bisa membuat keputusan dan siap mempertanggungjawabkan tiap akibat dari keputusan yang ia buat.6

Fungsi pendidikan budaya dan karakter bangsa menurut Hasan adalah, (1) Pengembangan: pengembangan potensi peserta didik untuk menjadi pribadi berperilaku baik, (2) perbaikan: memperkuat kiprah pendidikan nasional untuk bertanggungjawab dalam pengembangan potensi peserta didik yang lebih bermartabat, dan (3) penyaring: untuk menyaring budaya bangsa sendiri dan budaya bangsa lain yang tidak sesuai dengan nilai-nilai budaya dan karakter bangsa yang bermartabat.7 Djoko Santoso memaknai pendidikan karakter sebagai pendidikan nilai, budi pekerti, moral, watak yang bertujuan mengembangkan kemampuan peserta didik untuk memberikan keputusan, baik memelihara apa yang baik, mewujudkan dan menebarkan kebaikan kedalam kehidupan sehari-hari dengan sepenuh hati.8

Lickona mengartikan watak atau karakter sesuai dengan pandangan filosof Michael Novak, yakni Compatible mix of all those virtues identified by religions traditions, literary stories, the sages, and persons of common sense down through history.9 Oleh karena itu, Lickona memandang karakter atau watak itu memiliki tiga unsur yang saling berkaitan yakni moral knowing, moral feeling, and moral behavior atau konsep moral, rasa dan sikap moral dan perilaku moral.

Pendidikan karakter merupakan pendidikan nilai, pendidikan budi pekerti, pendidikan moral, pendidikan watak yang bertujuan mengembangkan kemampuan peserta didik untuk memberikan keputusan baik-buruk, memelihara apa yang baik, dan mewujudkan kebaikan itu dalam kehidupan

5 Mulyasa, Manajemen Pendidikan karakter. Jakarta: Bumi Aksara, 2014), 3.

6 Suyanto, "Urgensi Pendidikan Karakter", dalam kemdiknas.go.id., 2010, September 2015.

7 Hasan, Said Hamid, dkk, Pengembangan Pendidikan Budaya dan Karakter Bangsa, Jakarta: Kementrian Pendidikan Nasional Badan Penelitian dan Pengembangan, 2010), 7-10.

8 Maswardi Muhammad Amin, Pendidikan Karakter Anak Bangsa, (Jakarta: Baduose Media Jakarta, 2011), 5.

9 Lickona, Thomas, Educating for Character: How Our School Can Do Teach Respect and Responsibility, (New York: Brantam Book, 1991), 50-52. 
sehari-hari dengan sepenuh hati.10 Di lain pihak, Doni Koesoema menegaskan pendidikan karakter merupakan sebuah proses pendidikan yang terjadi dengan alamiah dan dilakukan secara natural serta informal, sesuai dengan formulasi tujuan pendidikan nasional. ${ }^{11}$

Tiga nilai respect, fairness, dan caring saling melengkapi dalam pembentukan karakter individu. Tiga nilai itu bersumber dari moral kesamaan sebagai makhluk Tuhan Yang Maha Esa sehingga mendorong individu berperilaku saling menerima dan menghormati keberadaan orang lain dalam kondisi apapun. ${ }^{12}$ Pendidikan karakter sebagai pendidikan nilai, pendidikan budi pekerti, pendidikan moral, pendidikan watak yang bertujuan mengembangkan kemampuan peserta didik untuk memberikan keputusan, baik memelihara apa yang baik, mewujudkan dan menebarkan kebaikan kedalam kehidupan seharihari dengan sepenuh hati. ${ }^{13}$

Pendidikan Karakter dalam Undang-Undang No. 20 tentang Sistem Pendidikan Nasional pada Pasal 3, "Pendidikan nasional berfungsi mengembangkan kemampuan dan membentuk watak serta peradaban bangsa yang bermartabat dalam rangka mencerdaskan kehidupan bangsa, bertujuan untuk berkembangnya potensi peserta didik agar menjadi manusia: 1) beriman dan bertaqwa kepada Tuhan yang Maha Esa; 2) berakhlak mulia; 3) Sehat; 4) Berilmu; 5) Cakap; 6) Kreatif; 7) mandiri; dan 8) menjadi warga negara yang demokratis serta bertanggung jawab." Jika dicermati lima dari sembilan potensi peserta didik tersebut, yang ingin dikembangkan sangat terkait erat dengan karakter yang berujung pada pembentukan mental bangsa dari dasar, merevolusi mental ${ }^{14}$

Karakter dasar yang menjadi tujuan pendidikan karakter dalam UU No. 20 tahun 2003 berakar pada Heritage Foundation yang telah merumuskan sembilan sembilan karakter sebagai berikut. 1) Cinta kepada Allah dan semesta beserta isinya; 2) Tanggung jawab, disiplin dan mandiri; 3) Jujur; 4) Hormat dan

10 Herry Widyastono, Pelaksanaan Pendidikan Karakter: Rencana Aksi Nasional Pendidikan Karakter, Jakarta: Pusat Kurikulum, 2010), 7.

11Albertus, Doni Koesoema, Pendidikan Karakter Utuh dan Menyeluruh, Yogyakarta: Kanisius, 2012), 4.

12 Santrock. J.W., Live Span Development, (Alih bahasa: Achmad Chusairi dan Yuda Damanik), (Jakarta: Erlangga, 1995), 286-287.

13 Maswardi Muhammad Amin, Pendidikan Karakter Anak Bangsa, (Jakarta: Baduose Media Jakarta, 2011), 5.

14 UU No. 20 tahun 2003 tentang Sistem Pendidikan Nasional. 
santun; 5) Kasih sayang, peduli, dan kerjasama; 6) Percaya diri; kreatif, kerja keras dan pantang menyerah; 7) Keadilan dan kepemimpinan; 8) Baik dan rendah hati serta; 9) Toleransi, cinta damai, dan persatuan. ${ }^{15}$ Dalam rangka lebih memperkuat pelaksanaan pendidikan karakter telah teridentifikasi 18 nilai yang bersumber dari agama, Pancasila, budaya, dan tujuan pendidikan nasional, yaitu: (1) Religius, (2) Jujur, (3) Toleransi, (4) Disiplin, (5) Kerja keras, (6) Kreatif, (7) Mandiri, (8) Demokratis, (9) Rasa Ingin Tahu, (10) Semangat Kebangsaan, (11) Cinta Tanah Air, (12) Menghargai Prestasi, (13) Bersahabat/Komunikatif, (14) Cinta Damai, (15) Gemar Membaca, (16) Peduli Lingkungan, (17) Peduli Sosial, \& (18) Tanggung Jawab. ${ }^{16}$

Kualitas karakter meliputi sembilan pilar kebangsaan, yaitu (1) Cinta Tuhan dan segenap ciptaan-Nya; (2) Tanggung jawab, Disiplin dan Mandiri; (3) Jujur/amanah dan Arif; (4) Hormat dan Santun; (5) Dermawan, Suka menolong, dan Gotong-royong; (6) Percaya diri, Kreatif dan Pekerja keras; (7) Kepemimpinan dan adil; (8) Baik dan rendah hati; (9) Toleran, cinta damai dan kesatuan. ${ }^{17}$ Dengan demikian, orang yang memiliki karakter baik adalah orang yang memiliki kesembilan pilar karakter kebangsaan tersebut. Kesembilan pilar karakter kebangsaan diajarkan secara sistematis dalam model pendidikan holistik menggunakan.

\section{Revolusi Mental}

Revolusi merupakan perubahan besar dan cepat, serta radikal untuk mempengaruhi kehidupan manusia. Di Indonesia, gaung dan semangat revolusi sudah ada sejak dulu, sejak Bung Karno (pemimpin tertinggi revolusi) menanamkan revolusi untuk merebut dan mempertahankan kemerdekaan. Kesuksesan awal dari revolusi di Indonesia adalah tercapainya kemerdekaan dan perlawanan dalam mengusir penjajahan. Namun, indikasi kemerdekaan harus dibarengi revolusi lainnya pernah diungkapkan Bung Karno bahwa revolusi Indonesia adalah revolusi pancamuka, revolusi multikompleks, revolusi yang

15 Mulyasa, E, Pengembangan dan Implementasi Kurikulum 2013: Perubahan dan Pengembangan Kurikulum 2013 Merupakan Persoalan Penting dan Genting, Bandung: Remaja Rosdakarya, 2013), 15.

16 Pusat Kurikulum, Pengembangan dan Pendidikan Budaya \& Karakter Bangsa: Pedoman Sekolah, Jakarta: Kemdiknas, 2009), 9-10.

17 Ratna Megawangi, Pendidikan Karakter untuk Membangun Masyarakat Madani, IPPK Indonesia Heritage Foundation, 2003), 12. 
bermuka banyak, ya revolusi nasional, ya revolusi politik, ya revolusi ekonomi, ya revolusi sosial, ya revolusi membentuk manusia Indonesia baru. ${ }^{18}$

Dalam melaksanakan revolusi mental, dapat menghasilkan "ketahanan pendidikan", yaitu Indonesia yang berdaulat dalam bidang pendidikan, dan Indonesia yang berkepribadian secara sosial-budaya, pendidikan yang mengkaji potensi yang dimiliki Indonesia dengan sebuah sistem pendidikan yang akuntabel, bersih dari praktik korupsi yang bisa dirasakan oleh seluruh anak bangsa, dan didukung oleh birokrasi yang bersih, handal, dan kapabel, yang benar-benar bekerja melayani kepentingan pendidikan dan mendukung pekerjaan guru untuk membentuk karakter siswa.

\section{Perangkat Pembelajaran}

Perangkat yang digunakan dalam proses pembelajaran disebut dengan perangkat pembelajaran. Perangkat pembelajaran yang diperlukan dalam mengelola proses belajar mengajar dapat berupa: silabus, RPP (Rencana Pelaksanaan Pembelajaran), LKS (Lembar Kerja Siswa), media pembelajaran serta modul siswa. ${ }^{19}$

\section{METODOLOGI PENELITIAN}

Penelitian ini dilakukan dengan menggunakan pendekatan "Penelitian Pengembangan" (Research and Development). Menurut Borg and Gall, model penelitian pengembangan adalah "a process used develop and validate educational product'.20 Dalam penelitian ini Research and Development dimanfaatkan untuk menghasilkan Perangkat Pembelajaran, yaitu penelitian yang berusaha merencang dan menciptakan prototipe perangkat pembelajaran dengan spesifikasi tertentu. Bahan ajar yang dikembangkan itu adalah perangkat pembelajaran bahasa Indonesia, siswa sekolah dasar kelas VI yang sesuai dengan Kurikulum Tingkat Satuan Pendidikan atau Kurikulum 2013 berbasis Subject Specific Pedagogy (SSP) terintegrasi pendidikan karakter dan revolusi mental.

18 Hamta, Firdaus, "Revolusi Mental dan Pendidikan Karakter", Online, http://batampos.co.id/, Kamis, 27 Nov 2014.

19 M. Nur Ibrahim, Pengembangan Perangkat Pembelajaran. Jakarta: Direktorat Pendidikan, 2000), 2-3.

20 Borg, W.R., and Gall, M.D., Educational Research: An Introduction. Fourth Edition, (New York: Longman, 1989), 782. 


\section{Prosedur Penelitian dan Pengembangan}

Tahap-tahap penelitian pengembangan yang dilakukan dalam penelitian sebagai berikut:

\section{Gambar 1: Langkah Integrasi Pendidikan Karakter dalam Pengembangan Perangkat Pembelajaran Bahasa Indonesia Berbasis SSP}

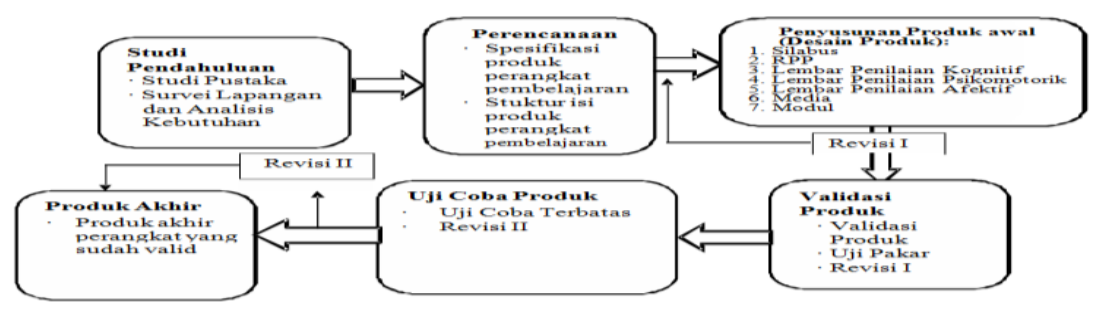

\section{Subjek Uji Coba}

Subjek uji coba ini dilakukan pada:

1. Siswa kelas VI SD di Kota Bandarlampung dengan kualifikasi unggul, sedang, dan rendah. Selain itu, subjek penelitian dapat berasal dari beberapa SD dengan kualifikasi yang berbeda. Jumlah siswa SD yang dijadikan sampel adalah 9 orang. Sebaran sekolah yang diuji coba adalah: SDN 1 Jagabaya, SDN 1 Kaliawi, dan SDN 2 Sumur Batu.

2. Guru SD yang mengajar di kelas VI di Kota Bandarlampung. Guru yang menjadi subjek penelitian yang berjumlah 3 orang. Sebaran sekolah yang diuji coba adalah: SDN 1 Jagabaya, SDN 1 Kaliawi, dan SDN 2 Sumur Batu.

3. Guru SD yang memahami kurikulum SD. Guru yang menjadi subjek penelitian yang berjumlah 3 orang. Sebaran sekolah yang diuji coba adalah: SDN 1 Jagabaya, SDN 1 Kaliawi, dan SDN 2 Sumur Batu.

4. Kepala SD yang dijadikan sebagai evaluator perangkat pembelajaran berjumlah 3 orang. Sebaran sekolah yang diuji coba adalah: SDN 1 Jagabaya, SDN 1 Kaliawi, dan SDN 2 Sumur Batu.

5. Dosen yang memiliki kompetensi mengenai kurikulum SD dan pembelajaran bahasa dan sastra Indonesia, berjumlah 2 orang sebagai 
validator perangkat pembelajaran bahasa Indonesia berbasis Subject Specific Pedagogy yang terintegrasi pendidikan karakter untuk siswa SD.

\section{Teknik Pengumpulan Data}

Data penelitian ini berupa survei, kemampuan siswa, kemampuan guru, dan hasil evaluasi terhadap prototipe perangkat pembelajaran. Teknik pengumpulan data yang digunakan untuk menjaring data penelitian ini adalah angket dan wawancara, daftar cek, tes, dan lembar observasi. Pada tahap awal ini (tahap prasurvei) instrumen yang digunakan barulah angket dan wawancara.

\section{Teknik Analisis Data}

Data penelitian ini berupa data kualitatif dan kuantitatif. Oleh karena penelitian ini baru pada tahap analisis kebutuhan, hanya data angket dan wawancara yang dinalisis. Adapun prosedur analisis data penelitian adalah: 1) mentabulasi data dari angket dan wawancara, 2) menganalisis data hasil tabulasi, 3) menginterpretasi hasil tabulasi, 4) menyimpulkan, dan 5) menganalisis data yang diperoleh dari hasil survei.

\section{HASIL PENELITIAN DAN PEMBAHASAN}

\section{Hasil Uji Coba Validasi Produk Awal (Draft I)}

Hasil validasi dari produk perangkat pembelajaran oleh dosen ahli adalah semua perangkat dalam kategori "Sangat Baik" walaupun dengan skor yang berbeda, akan tetapi telah memenuhi kriteria rentang skor kategori sangat baik. Hasil validasi dari produk perangkat pembelajaran oleh kepala sekolah adalah semua perangkat dalam kategori "Sangat Baik" walaupun dengan skor yang berbeda akan tetapi telah memenuhi kriteria rentang skor kategori sangat baik. Hasil validasi dari produk perangkat pembelajaran oleh guru adalah semua perangkat dalam kategori "Sangat Baik" walaupun dengan skor yang berbeda akan tetapi telah memenuhi kriteria rentang skor kategori sangat baik.

\section{Hasil Tahap Uji Coba Terbatas}

Tahap uji coba merupakan analisis uji coba perangkat pembelajaran SSP Bahasa Indonesia kelas VI terintegrasi pendidikan karakter yang diuji coba secara terbatas dan secara luas. Uji coba perangkat pembelajaran dilakukan selama dua jam pelajaran ( 2 x 40 menit) selama 1 pertemuan ditambah dengan penugasan yang diberikan kepada siswa di luar kelas. Hasil data yang diperoleh dalam uji coba terbatas sebagai berikut : 
a. Keterlaksanaan Pembelajaran dan Mengelola KBM

Hasil keterlaksanaan pembelajaran mengacu pada rencana pelaksanaan pembelajaran pada pertemuan 1 kepada 9 orang siswa. Hasil uji keterlaksanaan pembelajaran dan mengelola KBM. Hasil uji keterlasanaan pada uji coba terbatas diperoleh dari satu orang pengamat, yaitu guru yang melakukan uji coba terbatas. Hasil uji keterlaksanaan pada pertemuan pertama pada 2 jam pelajaran ini adalah $75 \%$. Pembelajaran telah dilakukan hampir sepenuhnya, hanya pada penilaian belum dilakukan karena evaluasi atau penugasan dilakukan di luar kelas sebagai pekerjaan rumah.

b. Respons Siswa terhadap Pembelajaran

Pada uji coba terbatas diperoleh 9 respon siswa yang menjadi subjek uji coba terbatas. Hasil respon 9 siswa terhadap pembelajaran dalam uji coba terbatas produk perangkat pembelajaran pada aspek orientasi hasil respon siswa adalah 3,7, aspek pengembangan karakter 3, 2, dan pengembangan keterampilan psikomotor adalah 3. Rata-rata dari ketiga aspek tersebut adalah 3,3 dengan kategori baik.

c. Tes Hasil Belajar

Tes hasil belajar pada produk perangkat pembelajaran ini adalah berupa angket yang meliputi pemahaman pada Nilai Karakter dan Nilai Mentalitas Bangsa.

\section{Pembahasan Hasil Penelitian dan Pengembangan}

\section{Pembahasan Hasil Tahap Penyusunan Produk Awal (Desain Produk Awal)}

Pada penyusunan pengembangan produk awal yaitu pengembangan draft perangkat pembelajaran meliputi: silabus, rencana pelaksanaan pembelajaran (RPP), media pembelajaran, kisi-kisi penilaian, lembar penilaian produk kognitif, kunci jawaban dan petunjuk penilaian, rubrik penilaian psikomotorik, lembar penilaian psikomotorik, rubrik penilaian afektif, lembar penilaian afektif, dan modul siswa berbasis Subject Specific Pedagogy (SSP).

a. Pengembangan Silabus

Pembuatan silabus mengacu pada Peraturan Mendiknas No. 41 tahun 2007 mengenai Standar Proses untuk Satuan Pendidikan Dasar dan Menengah. Pengembangan silabus sesuai dengan prinsip-prinsip 
pengembangan silabus yaitu ilmiah, relevan, sistematis, konsisten, memadai, aktual dan kontekstual, serta fleksibel.

b. Pengembangan RPP

Komponen-komponen penting dalam rencana pelaksanaan pembelajaran meliputi: standar kompetensi (SK), kompetensi dasar (KD), indikator pencapaian hasil belajar, tujuan pembelajaran, strategi pembelajaran, sumber pembelajaran, alat dan bahan, langkah-langkah kegiatan pembelajaran, dan evaluasi.

c. Pengembangan Modul

Modul merupakan panduan dalam kegiatan pembelajaran yang memuat materi pembelajaran, kegiatan penyelidikan berdasarkan konsep, keterampilan berbahasa, informasi, dan contoh-contoh penerapan keterampilan berbahasa dalam komunikasi sehari-hari. Pengembangan modul ini menggunakan desain individual learning yang didesain berbasis masalah dengan arahan dari guru yang mengintegrasikan belajar berbasis masalah dengan pendidikan karakter yang dimunculkan setelah melakukan kegiatan yang berada di modul.

d. Media Pembelajaran

Hasil analis kebutuhan sekolah dengan ketersediaan sarana LCD, masih belum dimanfaatkan secara optimal oleh guru. Berdasarkan hasil tersebut maka dapat dikembangkan media pembelajaran sebagai pelengkap pembelajaran di kelas untuk menunjang pemahaman siswa dalam pembelajaran

e. Pengembangan perangkat penilaian

Berdasarkan data pada analisis kebutuhan dan observasi sekolah, guru masih secara otentik melakukan penilaian kognitif akan tetapi belum mempunyai rubrik yang jelas dalam menilai afektif dan psikomotor. Walaupun di dalam rapor siswa tercantum nilai kognitif, afektif, dan psikomotor, tetapi terkhusus pada penilaian afektif dan psikomotor guru tidak menggunakan penilaian yang sistematis sehingga nilai yang dihasilkan di rapor pada aspek afektif dan psikomotor mempunyai indikator yang jelas. 


\section{Pembahasan Hasil Tahap Validasi Produk Awal dan Revisi}

Produk yang telah dikembangkan selanjutnya melalui tahap validasi. Tahapan ini dilakukan oleh 2 validator dosen ahli, 3 kepala sekolah, dan 3 guru. Berdasarkan hasil penilaian yang didapatkan, secara umum menilai bahwa silabus yang dikembangkan berkategori "Sangat Baik". Berdasarkan hasil penilaian yang didapatkan, secara umum, validator menilai bahwa RPP yang dikembangkan berkategori "Sangat Baik".

Dalam validasi lembar penilaian psikomotorik secara umum semua validator menilai bahwa Lembar Penilaian Psikomotorik berkategori "Sangat Baik". Dalam validasi lembar penilaian afektif (karakter) secara umum semua validator menilai bahwa Lembar Penilaian afektif berkategori "Sangat Baik". Secara umum, validator memberikan penilaian terhadap modul dengan kategori "Sangat Baik". Hasil validasi media pembelajaran sebagai pelengkap perangkat pembelajaran yang digunakan siswa dan guru baik di dalam kelas maupun di luar kelas. Secara umum, media pembelajaran dinilai "Sangat Baik" oleh kesembilan validator (dosen, guru, dan teman sejawat).

\section{Pembahasan Hasil Tahap Uji Coba Produk Skala Terbatas}

Dalam uji coba terbatas ini, dilakukan dengan mengujicobakan perangkat pembelajaran hasil revisi dari validator kepada 9 siswa. Pelaksanaan uji coba terbatas ini dilakukan dilakukan di luar pelajaran reguler di kelas. Oleh karena itu dalam pengujian perangkat pembelajaran ini dapat dikondisikan seperti pembelajaran di kelas dengan uji keterlaksanaan pada uji terbatas dilakukan lembar observasi keterlaksanaan pembelajaran yang diisi oleh guru.

\section{SIMPULAN}

Berdasarkan hasil analisis data dan pembahasan yang telah dilakukan dapat disimpulkan beberapa hal sebagai berikut : Pengembangan perangkat pembelajaran Bahasa Indonesia kelas VI SD berbasis Subject Specific Pedagogy (SSP) terintegrasi pendidikan karakter dilakukan menggunakan 7 langkah atau metode Research and Development oleh Borg \& Gall yang dimodifikasi dengan membatasi langkah penelitian dan menghasilkan suatu produk yang divalidasi dan diuji coba. Kualitas produk perangkat pembelajaran yang dikembangkan melalui serangkaian uji validitas oleh validator ahli, guru, dan teman sejawat dilanjutkan uji coba terbatas meliputi uji keterlaksanaan pembelajaran, respons siswa, dan uji coba tes hasil belajar mendapatkan nilai dengan kategori sangat baik sehingga perangkat pembelajaran yang dikembangkan layak digunakan. 
Pencapaian hasil belajar pada aspek karakter yang paling tinggi adalah jujur, rasa ingin tahu, disiplin, dan kerja keras.

\section{DAFTAR PUSTAKA}

Albertus, Doni Koesoema. 2010. Pendidikan Karakter Strategi Mendidik Anak di Zaman. Global. Jakarta: Garsindo

Albertus, Doni Koesoema. 2012. Pendidikan Karakter Utuh dan Menyeluruh. Yogyakarta: Kanisius.

Borg, W.R., and Gall, M.D., 1989. Educational Research: An Introduction. Fourth Edition, New York: Longman.

Hasan, Said Hamid, dkk,. 2010. Pengembangan Pendidikan Budaya dan Karakter. Bangsa. Jakarta: Kementrian Pendidikan Nasional Badan Penelitian dan Pengembangan.

Ibrahim, M. Nur. 2000. Pengembangan Perangkat Pembelajaran. Jakarta: Direktorat Pendidikan

Lickona, Thomas. 1991. Educating for Character: How Our School Can Do Teach Respect and Responsibility. New York: Brantam Book.

Maswardi Muhammad Amin, 2011. Pendidikan Karakter Anak Bangsa, Jakarta: Baduose Media Jakarta.

Megawangi, Ratna. 2003. Pendidikan Karakter untuk Membangun Masyarakat Madani. IPPK Indonesia Heritage Foundation.

Mulyasa, E. 2013. Pengembangan dan Implementasi Kurikulum 2013: Perubahan dan Pengembangan Kurikulum 2013 Merupakan Persoalan Penting dan Genting, Bandung: Remaja Rosdakarya.

Mulyasa. 2014. Manajemen Pendidikan karakter. Jakarta: Bumi Aksara.

Noll, James Wm. Taking Sides: Clashing Views On Controversial Educational Issues. United States of America: McGraw-Hill/Duskin.

Prasetyo, Zuhdan K., dkk. 2011. "Pengembangan Subject Specific Pedagogy (SSP) Berbasis Lima Domain Sains Untuk Menanamkan Karakter Siswa SMP". Makalah Seminar "Peranan Budaya dan Inovasi Pembelajaran dalam Pemantapan Pendidikan Karakter” Unika Atmajaya Jakarta.

Pusat Kurikulum. 2009. Pengembangan dan Pendidikan Budaya \& Karakter Bangsa: Pedoman Sekolah. Jakarta: Kemdiknas 
66 | AR-RIAYAH : Jurnal Pendidikan Dasar vol. 2, no. 1, 2018

Santrock. J.W. 1995. Live Span Development. (Alih bahasa: Achmad Chusairi dan Yuda Damanik). Jakarta: Erlangga.

UU No. 20 tahun 2003 tentang Sistem Pendidikan Nasional

Wahyu. 2011. "Masalah \& Usaha Membangun Karakter Bangsa”, Artikel. Jurnal Komunitas.

Widyastono, Herry. 2010. Pelaksanaan Pendidikan Karakter: Rencana Aksi Nasional Pendidikan Karakter. Jakarta: Pusat Kurikulum.

Hamta, Firdaus, "Revolusi Mental dan Pendidikan Karakter", Online, http://batampos.co.id/, Kamis, 27 Nov 2014

Suyanto. 2010. "Urgensi Pendidikan Karakter". kemdiknas.go.id. diunduh pada September 2015. 